\title{
Positive and Negative Constitutional Rights
}

\author{
David P. Currie $†$
}

In November, 1980, in Joliet, Illinois, a car turned over and caught fire. A policeman arrived and began directing traffic away from the scene. He made no effort to determine whether or not there were people in the car. There were, and they burned to death. The city was sued for damages on the ground that, by failing to save the occupants, the policeman and therefore the city had deprived them of life or liberty without due process of law.

Relief was denied. Our Constitution, wrote Judge Posner, "is a charter of negative rather than positive liberties. . . The men who wrote the Bill of Rights were not concerned that Government might do too little for the people but that it might do too much to them. The Fourteenth Amendment, adopted in 1868 at the height of laissez-faire thinking, sought to protect Americans from oppression by state government, not to secure them basic governmental services." Thus the city had no constitutional duty to help the accident victims, and thus its failure to act deprived them of neither liberty nor life. ${ }^{2}$

The question is important. If government has an affirmative duty to help accident victims, it may have other positive duties as well. It may have a duty to protect people against hostile acts of third parties such as theft and murder. It may also have a duty to protect them from hunger and disease. Judge Posner's broad denial of the existence of "positive liberties" seems to reject any such obligation. He is telling us, among other things, that there is no constitutional right to welfare benefits.

The language of the constitutional provision seems to support Judge Posner's conclusion. Like so many of the provisions of the

$\dagger$ Harry N. Wyatt Professor of Law, University of Chicago. My thanks to the University of Chicago Law School, where the essence of this paper was delivered as the Wilber G. Katz Memorial Lecture in November, 1985; to Erhard Denninger of the University of Frankfurt, with whom I explored the issues here considered during a joint seminar on comparative constitutional law; and to Gerhard Casper, Barbara Flynn Currie, Phil C. Neal, and Cass Sunstein for invaluable advice and encouragement.

1 Jackson v. City of Joliet, 715 F.2d 1200, 1203 (7th Cir.), cert. denied, 465 U.S. 1049 (1983).

2Id. at 1206. 
Bill of Rights, from which it was copied, the due process clause is phrased as a prohibition, not an affirmative command:" "nor shall any State" is the equivalent of "a State shall not." Moreover, what the states are forbidden to do is to "deprive" people of certain things, and depriving suggests aggressive state activity, not mere failure to help. The contrast with provisions of the same document imposing duties to conduct a census, ${ }^{4}$ to return fugitives, ${ }^{5}$ and to guarantee a republican form of government other constitutions explicitly recognizing affirmative rights to various social services ${ }^{7}$-suggests that when constitution-makers impose affirmative government obligations they tend to say so.

History, as Judge Posner says, also tends to support his conclusion. The ratification debates and the preamble to the resolution proposing the Bill of Rights contain repeated references confirming Madison's explanation that the Bill of Rights was designed to protect against "abuse of the powers of the General Government," and in particular to limit the powers of Congress. ${ }^{8}$ The

3 The clause reads, "[N]or shall any State deprive any person of life, liberty, or property, without due process of law. . . ." U.S. ConsT. amend. XIV, § 1 .

- Id. art. I, § 2, cl. 3 ("Representatives and direct Taxes shall be apportioned among the several States . . . according to their respective Numbers . . . The actual Enumeration shall be made within three Years after the first Meeting of the Congress . . . and within every subsequent Term of ten Years. ....").

' Id. art. IV, § 2, cl. 2 ("A Person charged in any State with Treason, Felony, or other Crime, who shall flee from Justice, and be found in another State, shall on demand of the executive Authority of the State from which he fled, be delivered up. . ..").

- Id. art. IV, §4 ("The United States shall guarantee to every State in this Union a Republican Form of Government, and shall protect each of them against Invasion. . . ."); see also id. art. I, \& 6, cl. 1 ("The Senators and Representatives shall receive a Compensation for their Services, to be ascertained by Law, and paid out of the Treasury. . . .").

' See, e.g., Constirumion tit. Ier (France 1791) (quoted infra at text accompanying note 17); Constitution preamble (France 1946) ("The Nation ensures to the individual and the family the conditions necessary to their development" and "guarantees to all . . . protection of health [and] material security"; those "unable to work [have] the right to obtain from the community the means to lead a decent existence."); Verrassung DES DeUTCHEN Reichs arts. 119, 143, 145, 161, 163 (Weimar Republic, Ger. 1919) (enumerating rights to education, national insurance, and employment or unemployment compensation); CoNSTITUTION arts. 40, 42, 44-46 (U.S.S.R. 1977) (enumerating rights to employment, health protection, housing, education, and culture); cf. Universal Declaration of Human Rights, G.A. Res. 217, U.N. Doc. A/III, art. 22 (1948) ("Everyone, as a member of society, has the right to social security. . . ."); id. art. 23 ("the right to . . protection against unemployment"); id. art. 25 ("the right to a standard of living adequate for . . . health and well-being"); id. art. 26 ("the right to education").

- See, e.g., 1 Debatzs on the Federal Constitution 338 (J. Elliot ed. 1836) (Congressional resolution explaining that several conventions had "expressed such a desire, in order to prevent misconstruction or abuse of its powers"); 2 id. at 177 (Massachusetts resolution proposing amendments to "guard against an undue administration of the federal government"); 2 id. at 396-406 (Mr. Tredwell expressing fears of excessive federal power); 3 id. at 
Framers would have been astounded to hear it contended that by adopting the Bill of Rights they had managed to make mandatory the exercise of a Congressional power to help needy citizens when the very existence of such a power was reasonably doubted as recently as the 1930s: $: 9$ And, given the absence of evidence in the debates, it is hard to believe the due process clause of the fourteenth amendment was meant to have a radically different effect from that of the fifth. ${ }^{10}$

Moreover, Supreme Court jurisprudence yields additional support for Judge Posner's thesis. The paucity of early decisions employing constitutional guarantees to compel governments to care for needy citizens suggests something about the original understanding. The numerous decisions recognizing that the fourteenth amendment limits only government and not private action suggest a principle that cannot be avoided by rephrasing the complaint to attack official failure to prevent private activity. ${ }^{11}$ More pointedly, as Judge Posner noted, the recent decisions denying an obligation to pay for abortions are squarely based upon his conception that the due process clauses confer rights of protection from rather than by the government:"12 "although government may not place obstacles in the path of a woman's exercise of her freedom of choice, it need not remove those not of its own creation."13

461 (Mr. Henry articulating similar concerns); 1 Annals of Cong. 449-50, 454-55 (J. Gales ed. 1789) (remarks by Mr. Madison).

' See, e.g., United States v. Butler, 297 U.S. 1, $62-70$ (1936) (finally rejecting the argument that the federal spending power was limited to that necessary to carry out other enumerated powers, but limiting conditional grants). Indeed, the ninth amendment seems to have been adopted precisely to prevent using the Bill of Rights as the basis for a broad construction of congressional powers. See David Currie, The Constitution in the Supreme Court-The First Hundred Years 48-49 (1985).

${ }^{10}$ See The Slaughter-House Cases, 83 U.S. (16 Wall.) 36, 80 (1873) (Miller, J.) (equating the restrictions of the fourteenth amendment with those of the fifth).

" See, e.g., The Civil Rights Cases, 109 U.S. 3, 17 (1883) (the "wrongful act of an individual, unsupported by any [state] authority, is simply a private wrong, or a crime of that individual").

12 See Jackson v. City of Joliet, 715 F.2d 1200, 1203 (7th Cir.) (citing Harris v. MacRae, 448 U.S. 297 (1980)), cert. denied, 465 U.S. 1049 (1983), for the proposition that the Constitution is a "charter of negative liberties."

${ }^{13}$ Harris, 448 U.S. at 316 . The Court added, "It cannot be that because government may not prohibit the use of contraceptives, . . . or prevent parents from sending their child to a private school, ... government, therefore, has an affirmative constitutional obligation to ensure that all persons have the financial resources to obtain contraceptives or to send their children to private schools." Id. at 318 (citations omitted); accord Maher v. Roe, 432 U.S. 464, 474 (1977) ("The indigency that may make it difficult-and in some cases, perhaps, impossible-for some women to have abortions is neither created nor in any way affected by the Connecticut regulation."). The dissenters in Harris did not rely on the argument that the government deprives a person of a right by not subsidizing its exercise, but on 
In the face of this array of powerful arguments supporting Judge Posner's position, one might be tempted to dismiss a rather noisy collection of contrary academic assertions as wishful thinking. ${ }^{14}$ An interesting series of decisions in West Germany, however, finding affirmative government duties largely on the basis of provisions phrased somewhat the same way as ours, suggests that Judge Posner's conclusion may not be so obvious as it may seem. I shall first discuss the German decisions and then take a closer look at our own.

\section{German Decisions}

Anatole France's mockery of a law that forbade the rich as well as the poor to sleep under bridges ${ }^{15}$ was representative of a growing conviction that governments ought to start taking more affirmative action to benefit the people. As early as 1758, Montesquieu had argued that the state "owed all citizens," among other things, "nourishment, suitable clothing, and the opportunity for a healthy life."16 The French Constitution of 1791 acknowledged such a duty by imposing an obligation on government to establish not only a system of free public education but also a system of public assistance "to bring up abandoned children, relieve poor invalids, and furnish work to the able-bodied poor who cannot obtain it for themselves."17

Of more direct relevance to the question of interpretation were those who, instead of taking the position that liberty was not

the contention that by discriminating against abortions in the context of a program paying for other services, the government had indeed placed obstacles in the way of obtaining an abortion. Harris, 448 U.S. at 330 (Brennan, Marshall, and Blackmun, JJ., dissenting). For a similar argument see Bennett, Abortion and Judicial Review: Of Burdens and Benefits, Hard Cases and Some Bad Law, 75 Nw. U.L. Rev. 978, 1008-10 (1981).

Analogies from other fields of the law also support Judge Posner. In neither criminal nor tort law are people generally held responsible for mere failure to help others. See, e.g., P. Keeton, D. Dobbs, R. Keeton \& D. Owen, Prosser \& Kreton on the Law of Torts 373 (5th ed. 1984) [hereinafter cited as Prosser \& Kreton] ("The highly individualistic philosophy of the older common law had no great difficulty in working out restraints upon the commission of affirmative acts of harm, but shrank from converting the courts into an agency for forcing men to help one another.").

14 See, e.g., Michelman, Foreword: On Protecting the Poor Through the Fourteenth Amendment, 83 Harv. L. REv. 7 (1969); Miller, Toward a Concept of Constitutional Duty, 1968 Sup. CT. Rev. 199; Bendich, Privacy, Poverty, and the Constitution, 54 Cal. L. Rev. 407 (1966). For a defense of the traditional contrary view see Bork, The Impossibility of Finding Welfare Rights in the Constitution, 1979 WASH. U.L.Q. 695.

15 Anatole France, Le Lys Rouge (1894).

16 2 BAron De Montesquiru, Esprit Des Lois (V. Pritchard ed. 1898).

${ }^{17}$ Constitution tit. Ier. (France 1791) (author's translation). 
enough, undertook to define the term itself to include positive government duties. The English philosopher Thomas Hill Green, for example, emphatically denied that liberty consisted solely of the absence of legal restraint, insisting that it was instead "the positive power or capacity of doing or enjoying something," and thus that affirmative government aid might be essential to liberty. ${ }^{18}$

There continued to be those who argued that, however justified the call for affirmative government action, this was a misuse of the term "liberty." Isaiah Berlin, for example, pointed out that the inability of humans to fly was not generally thought of as lack of freedom. ${ }^{19}$ In imposing a number of affirmative obligations on the German government in 1919, the Weimar Constitution did so expressly and without referring to liberty or freedom. ${ }^{20}$ The influential German scholar Carl Schmitt, writing in 1928, was quick to assert that such "socialistic" rights as these, for which he evidently had little sympathy, were not what was meant by "basic rights" at all. The latter consisted rather of defensive rights ("Abwehrrechte") assuring a "limited possibility of governmental intrusion": "Basic rights in the true sense are therefore only rights of individual freedom, not social demands" on the state for the provision of services. ${ }^{21}$

The current Basic Law of the Federal Republic of Germany, adopted in 1949, differs in a great many respects from the Weimar Constitution, not least in its omission of specific governmental duties to provide such services as education, employment, and social insurance. ${ }^{22}$ Preserved and strengthened, on the other hand, is a collection of "basic rights" tional catalogue of defensive rights described by Schmitt and by Judge Posner. Every person has, for example, "the right to life."24

18 Thomas H. Green, Liberal Legislation and Freedom of Contract, in 3 Works 371 (R. Nettleship 3d ed. 1891) (arguing that some government limitations on freedom of contract actually increased liberty).

19 Isaiah Berlin, Two Concepts of Liberty 7 (1958).

20 Verfassung des Deutschen Reichs arts. 119, 143, 145, 161, 163 (Weimar Republic, Ger. 1919).

${ }^{21}$ Carl Schmitt, Verfassungslehre 163-70 (1928). Schmitt's evident distaste for social rights was suggested not only by his disdainful use of the term "socialistic" but also by his earlier flat statement that the goal of a modern constitution was "protection of the citizen from the misuse of governmental power." Id. at 126.

${ }^{22}$ There is one exception: "Every mother has a claim to the protection and support of the community." GrundGesETz [GG] art. 6, abs 4 (W. Ger.) (translation by the Press and Information Office of the Federal Government, Bonn).

${ }^{23} \mathrm{GG}$ art. 1, abs. 3.

24 Id. art. 2, abs. $2, \S 1$. 
The "liberty of the individual"2s and "freedom of faith, of conscience," and of "religious or ideological" creed are "inviolable."26 Everyone has the "right freely to express and disseminate his opinion,"27 and all Germans have "the right freely to choose their trade, occupation, or profession, their place of work and their place of training." 28 The express provision that the rights listed are binding on all organs of government ${ }^{29}$ seems to exclude any inference that they also apply directly to the actions of private parties. The social obligations of government seem to be summed up in the cryptic and on its face merely descriptive statement that the Federal Republic "is a democratic and social federal state."so

It was against these provisions, on their face so similar to our own, that the German Constitutional Court was called upon in 1975 to measure a statute regulating the right to abortion. The result, for the observer from the United States, was arresting. Our Supreme Court, at about the same time, had held the due process clause forbade the state generally to make abortion a crime. The German court held that a similarly worded clause required it to do so. ${ }^{\text {s1 }}$

The first step in the German court's reasoning was to conclude, contrary to our Supreme Court, that the fetus was, in essence, a person whose life was among those protected by the Basic Law. ${ }^{32}$ This conclusion alone, however, did not compel the decision that the constitution required the state to punish abortion in general. For many abortions are performed not by governments but by private parties, and, as already noted, the right to life seemed to be guaranteed, as it is in the United States, against government alone. Without disputing this conclusion, the court focused upon the government's inaction and took the step that Judge Posner, and our

25 Id. art. 2, abs. $2, \S 2$.

${ }^{28}$ Id. art. 4; abs. 1 .

${ }^{27}$ Id. art. 5 , abs. $1, \S 1$.

2s Id. art. 12 , abs. $1, \S 1$.

29 Id. art. 20, abs. 3 .

so Id. art. 20 , abs. $3, \S 1$. Article 28 , abs. $1, \S 1$, makes the general social-state principle binding on the individual states (Länder) that make up the Federation ("The constitutional order in the Länder must conform to the principles of republican, democratic and social government . . . within the meaning of this Basic Law"), but most of the decisions discussed below involved actions of the central government.

s1 Compare Roe v. Wade, 410 U.S. 113 (1973), with Entscheidungen des Bundesverfassungsgerichts [BVerfG] 39, 1 (1975). An English translation of the German decision appears at 9 John Marshall L. Rev. 551 (1976). American commentary on the decision includes Kommers, Abortion and the Constitution: United States and West Germany, 225 AM. J. Comp. L. 255 (1977).

32 BVerfGE 39, 20 (1975). 
Supreme Court in the abortion-funding cases, refused to take: it interpreted a provision recognizing a right to life against government as imposing an affirmative duty to protect life from menaces not of the government's making. The Basic Law, the court declared, not only "prohibits . . . direct governmental encroachments upon the developing life, but also commands the State . . . to safeguard it from illegal encroachments by others."

There were dissenting opinions, but not on this point; the only disagreement was over whether criminal sanctions were the only acceptable way for the state to carry out its affirmative obligation. ${ }^{34}$ The basic conclusion that the constitutional provision guaranteeing a right to life requires affirmative protection against third parties is widely supported in the German literature, ${ }^{35}$ and it has been confirmed in later decisions-although without finding additional cases in which existing law provided inadequate protection. ${ }^{36}$

Other German decisions, moreover, have applied the same reasoning to find in similarly worded provisions government obligations to protect the individual not from third parties but from what may appear to be adverse physical or economic conditions. First, in 1960, in striking down a federal statute setting up a government-controlled television network, the constitutional court relied in part upon the provision that "freedom of reporting by means of broadcasts" was "guaranteed." 37 This provision, the court said, "contains more than just the citizen's right that the state respect a sphere of freedom in which he can express his opinions without hindrance." ${ }^{\text {38 }}$ Because both technical and economic factors dictated that "in the broadcasting field the number of stations must remain small," 39 "[b]roadcast stations must . . . be so organized that all interests worthy of consideration have an influence in their governing councils and can express themselves in the overall

ss Id. at 42 (author's translation).

34 See id. at 69.

ss See, e.g., Denninger, Einleitung vor Art. 1, in Kommentar zUM Grundgesetz pUr die BundesRepublik Deutschland 256-66 (1985); Schneider, Eigenart und Funktionen der Grundrechte im demokratischen Verfassungsstaat, in Joachim Perels, Grundrechte als Fundament der Demokratie 11, 40 (1979); Konrad Hesse, Grundzuge des VerfassungsRECHTS DER BUNDESREPUBLIK DEUTSCHLAND 146-47 (12th ed. 1980).

${ }^{36}$ See, e.g., BVerfG 46, 160, 162 (1977) (citizens are entitled to protection from terrorists); BVerfG 49, 89, 142 (1978) (state has a duty under the Basic Law to regulate nuclear emissions); BVerfG 53, 30 (1979) (state has a duty to regulate nuclear power plants); BVerfG 56, 54, 63 (1981) (state has a duty to regulate airport noise).

37 GG art. 5, abs. 1 .

ss BVerfG 12, 205, 259-60 (1960) (author's translation).

39 Id. at 261. 
program." "40 Similarly, in 1972, the German court interpreted a provision guaranteeing that "[a]ll Germans shall have the right freely to choose . . . their place of training"41 to impose a duty on the state to provide schooling. "The constitutional protection of basic rights in the field of education is not limited to the protective function against governmental intervention traditionally ascribed to the basic rights." 2 Because "the right would be worthless without the actual ability to make use of it," the entitlement "of every German to carry out his chosen study program if he demonstrates the requisite qualifications ... is not in the discretion of the lawmakers." ${ }^{33}$ In short, the German court, in sharp contrast to the view taken by Judge Posner and our abortion-funding cases, is firmly committed to the view that an assortment of provisions guaranteeing rights against government imposes affirmative governmental duties to protect the citizen.

Differences in phrasing make these decisions somewhat easier to justify under the German constitution than they would be under our own. In the abortion case, for example, the court invoked not only the right to life but also a provision making it the "duty of all state authority" not only to "respect" but also to "protect" the dignity of man."4 The "freedom" of broadcasting and the "right" to choose a place of training are "guaranteed" or simply declared, not merely protected against official abridgement. ${ }^{45}$ The social-state principle may plausibly be read as a direction to interpret basic rights in line with a more extensive understanding of the affirmative obligations of government. ${ }^{46}$ Even if the language of the two constitutions were the same, moreover, it would be arguable that the different social and political climates in which they had been adopted justified differing interpretations: James Madison and his

to Id. at 262-63. A generation later, in warning that the government's obligation would not disappear "even if in the course of modern development the special situation caused by shortage of transmitting frequencies and by the high financial expenditure needed for broadcasting productions no longer obtains," the court repeated that "it is a responsibility incumbent on the legislature to see that there will be an overall offering in which the multitude of opinions that is indispensable in a free democracy finds its expression." BVerfG 57, 295 (1981).

11 GG art. 1, abs. 1.

12 BVerfG 33, 303, 330 (1972).

1s Id. at 331 . Later in the opinion, after saying all this, the court professed to leave the question open. Id. at 333 .

14 GG art. 1, abs. 1, § 1. See BVerfG 39, 41 (1975); Denninger, Verfassungsrechtliche Schlüsselbegriffe, in Festschrift PUR Rudolf Wassermann 279, 280 (C. Broda ed. 1985) (emphasizing the use of the word "protect" in article 1).

15 Compare GG art. 5, abs. 1, and id. art. 12, abs. 1, with U.S. ConST. amend. I.

16 See Denninger, supra note 35, at 261; Schneider, supra note 35, at 33. 
friends were not modern social democrats. Neither the peculiar language of the German provisions nor the historical context of their adoption, however, was the deciding factor in the opinions; ${ }^{47}$ and in any event the contrast between Judge Posner's view and that of the German court is striking enough to suggest the desirability of taking a closer look at our own decisions.

\section{AmERICAN Rights AND Freedoms}

1. Goldberg $v$. Kelly. In this first of the so-called "new property" cases, the Court held that due process forbade the termination of welfare benefits in advance of certain procedures, where state law had granted an "entitlement" to qualified persons. ${ }^{48}$ Here is arguably an affirmative obligation of sorts: that the state may not stop paying means it must pay.

The scope of this "affirmative" obligation is obviously limited. First, the focus was entirely on procedure; nothing in the decision suggests that the state was required to go on providing welfare to the individual involved after making appropriate findings in a suitable proceeding. Moreover, there was nothing to suggest the state was required to create a welfare program to begin with, or even that it was forbidden to abolish a pre-existing program. Indeed in such a case as Goldberg the classification of the duty as affirmative is somewhat artificial: it is equally accurate to say, as the Court said, that the state was attempting to deprive the plaintiff of her preexisting right to payments in the most traditional sense. ${ }^{49}$

2. Remedies for Governmental Wrongs. In Ex parte Youngso the Supreme Court held, among other things, that a provision imposing fines so high as to discourage violating a law in order to test its validity worked a deprivation of property without due process of law. ${ }^{51}$ This and other decisions suggest there are times when the Constitution requires the state to provide a judicial remedy; and

47 Indeed some of the German decisions have attracted sharp criticism in their own country on the ground that the omission of a list of participatory rights such as that found in the Weimar Constitution forbade interpreting the basic rights to have the same effect. See, e.g., K. Hesse, supra note 35, at 123-24; cf. Forsthoff, Begriff und Wesen des sozialen

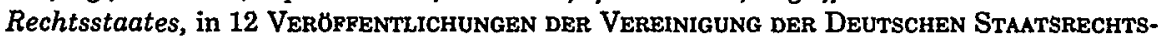
LEHRER 8, 23-27 (1954) (arguing that the social-state principle was not originally understood to have created enforceable individual rights).

48 Goldberg v. Kelly, 397 U.S. 254, 265 (1970).

19 Id. at 262 ("[Welfare] benefits are a matter of statutory entitlement for persons qualified to receive them. Their termination involves state action that adjudicates important rights.").

so 209 U.S. 123 (1908).

B1 Id. at 147. 
this may be described as an affirmative duty of government toward the citizen..$^{52}$

This description, however, entails looking only at a part of the transaction. Ex parte Young was not a case in which the state was required to remedy a deficiency attributable to impersonal forces or to someone else, as in the German cases. There was no doubt that the government had stepped forward aggressively to intervene in the life of the citizen: it had made it a crime to charge more than a specified rate for rail transportation. On John Marshall's thesis that constitutional rights are empty without courts to enforce them, ${ }^{53}$ governments may well be under some affirmative obligation to provide judicial remedies for their own violations of the Constitution. But cases like Young stand for no more than the modest proposition that this limited duty is indispensable to the traditional protection of the citizen against active governmental aggression. ${ }^{\text {p }}$

3. The Right to Counsel and Prisoners' Rights. The sixth amendment provides that one prosecuted for a crime "shall enjoy the right . . . to have the Assistance of Counsel for his defence." This looks like just another right to be left alone: the government may not prevent a criminal defendant from having a lawyer. Yet the Court has long held that it imposes an affirmative duty on the government to provide legal assistance if the defendant cannot afford it.ss

Is this an opening wedge for a general recognition of affirmative government duties in apparently defensive provisions? I think not. In the first place, the language of other provisions is not the same. The due process clauses explicitly require government deprivation, the first amendment requires government abridgement; the

${ }^{32}$ Cf. Ward v. Love County, 253 U.S. 17, 24 (1920) ("As the payment was not voluntary, ... no statutory authority was essential to enable or require the county to refund the money. . . . To say that the county could collect these unlawful taxes by coercive means and not incur any obligation to pay them back is nothing short of saying that it could take or appropriate the property . . . without due process of law."); General Oil Co. v. Crain, 209 U.S. 211 (1908) (in holding a state court could not dismiss a suit to enjoin an officer from enforcing an unconstitutional law on sovereign-immunity grounds, the Court stated, "If a suit against state officers . . . may be forbidden by a State to its courts, . . . an easy way is open to prevent the enforcement of many provisions of the Constitution").

ss See Marbury v. Madison, 5 U.S. (1 Cranch) 137, 176-77 (1803).

st Even Judge Posner recognizes that a state may take upon itself an affirmative duty of protection when it places an individual in a "position of danger." See Jackson v. City of Joliet, 715 F.2d 1200, 1204 (7th Cir.), cert. denied, 465 U.S. 1049 (1983); Bowers v. DeVito, 686 F.2d 615, 618 (7th Cir. 1982).

ss U.S. ConsT. amend. VI.

se See, e.g., Johnson v. Zerbst, 304 U.S. 458, 468 (1938). 
"right" to assistance of counsel is not so negatively phrased. ${ }^{.7}$ More important, as in the case of remedies for governmental aggression in Ex parte Young, to characterize the right to assigned counsel as involving an affirmative government duty is to look at only a part of the transaction. In convicting an individual of crime, the government reaches out to deprive him of life, liberty, or property by execution, jail, or fine. ${ }^{58}$

Thus, even in holding that the fourteenth amendment required the states to provide assigned counsel as well, the Court did not expand the definition of deprivation to encompass the failure to provide services; it merely determined what constituted the process due when the state sought actively to deprive the individual of life, liberty, or property by means of the criminal law. ${ }^{80}$ This can also be said of decisions imposing ostensibly "affirmative" duties to provide medical care, ${ }^{60}$ law books, ${ }^{61}$ or even religious services ${ }^{62}$ to persons in prison or otherwise disabled by government from obtaining them for themselves: ${ }^{63}$ by locking an individual up without providing such services, the government has deprived him of them in the most traditional sense.

4. Contract Clause Cases. From the very beginning, the Supreme Court has insisted that a state might impair the obligation of contract in violation of article $I$, section 10 if it deprived the

s7 The right to counsel also appears in tandem with other "rights," such as those to compulsory process and a jury trial, which unmistakably require affirmative action in this sense. See U.S. Const. amend. VI.

${ }^{38}$ Cf. Prosser \& KeEton, supra note 13, at 374 (noting that it is often difficult to distinguish between action and inaction, the authors write: "Failure to blow a whistle or to shut off steam, although in itself inaction, is readily treated as negligent operation of a train, which is affirmative misconduct").

${ }^{38}$ See, e.g., Gideon v. Wainwright, 372 U.S. 335, 341 (1963); cf. Johnson v. Zerbst, 304 U.S. at 463 ("The Sixth Amendment withholds from federal courts, in all criminal proceedings, the power and authority to deprive an accused of his life or liberty unless he has or waives the assistance of counsel.").

${ }^{\text {Bo }}$ See Estelle v. Gamble, 429 U.S. 97 (1976) (prison officials violate the eighth amendment's prohibition against "cruel and unusual punishment" when they show "deliberate indifference" to a prisoner's serious medical needs).

61 See, e.g., Bounds v. Smith, 430 U.S. 817 (1977) (prisoner's constitutional right of access to the courts requires prisons to furnish a law library); accord Younger v. Gilmore, 404 U.S. 15 (1971).

22 See Cruz v. Beto, 405 U.S. 319, 322 (1972) (finding a cause of action under 42 U.S.C. $\S 1983$ when the prisoner alleged deprivation of a "reasonable opportunity of pursuing his [Buddhist] faith comparable to the opportunity afforded fellow prisoners who adhere to conventional religious precepts").

6s See, e.g., Youngberg v. Romeo, 457 U.S. 307 (1982) (holding that a mentally retarded person involuntarily confined in a state institution has substantive rights under the due process clause). 
parties of pre-existing remedies for breach. ${ }^{64}$ When a state's own contracts were involved, this conclusion might be viewed as merely another example of the $E x$ parte Young principle that there must be a remedy for government aggression. But the rule was unhesitatingly applied to purely private contracts in cases like Bronson $v$. Kinzie, ${ }^{65}$ where the Court held that a state could not destroy a mortgagee's foreclosure rights by denying him an effective remedy.

This decision is a more serious challenge to Judge Posner's thesis than those we have previously considered, for in Bronson the Supreme Court unequivocally interpreted a provision forbidding government intrusion to require the government to protect the citizen against a third party. Moreover, the Court's logic was compelling. If the state were free to withdraw remedies, it could effectively impair the substantive obligation; ${ }^{68}$ for at least as early as Hobbes it had been recognized that a contractual right was worthless without state coercion. ${ }^{67}$

One must not overgeneralize from this example. Ogden $v$. Saunders ${ }^{68}$ made clear that it is only withdrawal of a previously existing right that offends the contract clause: there is no general obligation to protect contractual expectations, but there is an obligation to continue providing the protection originally afforded. ${ }^{69}$ Moreover, other clauses must be individually examined to see whether even this degree of state protection against third parties is indispensable to their functioning; not every clause expressly forbids the state to impair the rights of one citizen against another. Finally, the contract clause cases entailed government protection only against third parties, not against natural adversity. Indeed the very fact that the rights protected are those held against third parties, which justifies the limited affirmative obligation the Court found implicit in that clause, seems to forbid extending the precedents to hold that it also requires government protection against poverty or disease.

64 See, e.g., Green v. Biddle, 21 U.S. (8 Wheat.) 1 (1823).

es 42 U.S. (1 How.) 311, 320 (1843).

as The Court stated, "[N]o one, we presume, would say that there is any substantial difference between a retrospective law declaring a particular contract or class of contracts to be abrogated and void, and one which took away all remedy to enforce them, or encumbered it with conditions that rendered it useless or impracticable to pursue it." Id. at 317 .

67 See Thomas Hobbes, Leviathan ch. XIV (2d ed. London 1924) (1st ed. 1651).

25 U.S. (12 Wheat.) 213 (1827).

or Id. at 321-22. 
5. The Labor Injunction. In Truax v. Corrigan, ${ }^{70}$ in 1921, the Supreme Court held that a state could not constitutionally forbid injunctions against picketing by striking workers. One of the grounds relied on was that by withdrawing the injunctive remedy the state had deprived the employer of property without due process of law. ${ }^{71}$ Free access to his premises was a part of the right to land; picketing interfered with that right; and "[a] law which operates to make lawful such a wrong ... . deprives the owner of the business and the premises of his property without due process."72

Here is another example of an affirmative governmental duty: although it would have been easy to conclude as a linguistic matter that it was the picketers and not the state that had "deprived" the employer of his property, the Court interpreted the due process clause, despite its negative wording, to require the state to protect the employer against the acts of private parties. ${ }^{73}$

Once the Supreme Court had rejected the plausible historical argument that the due process clauses were meant only to assure an appropriate procedure in criminal cases, ${ }^{74}$ the logic of the Truax argument is strong. Property, like contract, entails a right against third parties that is worthless without government help. That it might suffice for the state to allow the householder to shoot burglars proves only that the state may have a broad range of choice among means of meeting its obligation, for the right of self-help would be no better than no property at all if the burglar were not legally disabled from fighting back. ${ }^{75}$ The state's obligation not to

${ }^{70} 257$ U.S. 312 (1921).

71 Id. at 328. Alternatively, the Court held that even if the statute withheld from the employer only the injunctive remedy, and not all other remedies, the statute failed as a violation of the equal protection clause of the fourteenth amendment insofar as it operated only against employers as a class. Id. at 334 .

72 Id. at 327-28.

${ }^{73}$ Cf. Battaglia v. General Motors Corp., 169 F.2d 254, 257 (2d Cir. 1948) (in upholding a limitation on federal jurisdiction to enforce claims under a retroactively repealed interpretation of the Fair Labor Standards Act only because the repeal was not itself unconstitutional, the Court stated, "[W]hile Congress has the undoubted power to give, withhold, and restrict the jurisdiction of courts other than the Supreme Court, it must not so exercise that power as to deprive any person of life, liberty, or property without due process of law or to take private property without just compensation.").

"See, e.g., Shattuck, The True Meaning of the Term "Liberty" in Those Clauses in the Federal and State Constitutions Which Protect "Life, Liberty, and Property," 4 Harv. L. REv. 365 (1891).

${ }^{75}$ Locke's description of the social compact suggests that government has assumed the affirmative obligation to afford greater protection than the individual enjoyed in a state of nature, not that it can absolve itself of responsibility by restoring the law of the jungle:

But though men when they enter into society give up the equality, liberty and executive power they had in the state of nature into the hands of society, ... yet it being 
deprive the owner of his property may thus, by analogy to the contract clause, implicitly include the duty not to withdraw pre-existing remedies against third parties. ${ }^{76}$

From Truax it may not be a giant step to the critical and at first glance startling conclusion of the German court in the abortion case that the government must affirmatively protect life as well. It is true that the argument that made Truax and the contract cases so compelling is weaker here. Unlike contract and property, life is not a legal construct whose only significance lies in protection against other human beings; to limit deprivations of life to direct government aggression would not drain the provision of its meaning. Yet it is hard to believe that the framers meant to require that theft and not murder be made a crime. Moreover, the social-contract theory that so pervaded early American political thought entails a surrender of the right of self-help in exchange for government protection not only of property but of life and liberty as well..$^{77}$ If the due process clauses embody this vision, it may not be amiss to conclude that they do so entirely and thus also require affirmative government protection of life and liberty. ${ }^{78}$

Once freed from the constraint of finding a right that would be meaningless without an obligation to protect against third parties, moreover, a court might be tempted to conclude that a government that deprives people of life by not punishing murder also does so by declining to feed the hungry or to rescue fire victims, and-contrary to Judge Posner's view-we would have discovered

only with an intention in every one the better to preserve himself, his liberty and property, . . . the power of the society, or legislative constituted by them, . . . is obliged to secure every one's property. . .."

John Locke, The Second Treatise of Government ch. IX (T. Peardon ed. 1952) (1st ed. 1690).

76 If this argument is accepted, it means only that a threshold requirement for the application of the clause has been met; it does not compel the Court's conclusion that the abolition of the injunctive remedy constituted a deprivation of property without due process of law. For discussion of the remaining issues in Truax see Currie, The Constitution in the Supreme Court: 1921-30, 1986 DukB L.J. 65, 71-76.

77 Indeed, Locke used the term "property" as a catch-all phrase for the interests of life, liberty, and property, and contended the people entered into civil society in order to preserve each of these interests. See J. Lo

${ }^{28}$ Thus it may have been not inattentiveness to the state-action requirement, but rather a broad conception of official deprivation that induced Justice Blackmun to suggest that if the fetus were considered a person it might be unconstitutional for a state to permit abortion. See Roe v. Wade, 410 U.S. 113, 157 n.54 (1973). For an argument that even if the unborn child is considered a person, no constitutional deprivation occurs when a private physician performs the abortion, see Epstein, Substantive Due Process by any Other Name: The Abortion Cases, 1973 Sup. CT. Rev. 159, 179-80. 
a constitutional right to basic welfare services. ${ }^{79}$

The greatest weakness of this logical step is that it is profoundly ahistorical. The night-watchman theory of government may have been in sufficient disrepute by 1949 , the year the Basic Law was adopted, to make it plausible for the German court to equate failure to protect against impersonal forces with failure to protect against third parties, but it was otherwise when the due process clauses were written. It is true in Locke's terms that Jean Valjean gave up the power to steal that precious loaf of bread as well as the power to punish those who trespassed against him; but Locke might have denied he had had the "right" to steal in a state of nature. ${ }^{80}$ And it seems fair to conclude that Chief Justice Taft, author of the Truax opinion, would have been among the last to believe that by that decision he had laid the foundation for a constitutional right to the provision of welfare.

6. The Public Forum Cases. In a series of decisions over the past half century, the Supreme Court has developed the principle that government may not forbid the use of certain public property by private persons for purposes of free expression. Some of these decisions can be explained on the ground of simple discrimination and therefore, for purposes of this inquiry, add nothing to the equal protection cases to be discussed below. ${ }^{81}$ Others invoking the

70 To extract this conclusion from the Court's short-lived position that Congress could not impose minimum wage requirements on state governments engaged in the provision of essential services, however, see Michelman, States' Rights and States' Roles: Permutations of "Sovereignty" in National League of Cities v. Usery, 86 YALE L.J. 1165 (1977) (finding in National League of Cities v. Usery, 426 U.S. 833 (1976), overruled, Garcia v. San Antonio Metropolitan Transit Auth., 105 S. Ct. 1005 (1985), the basis for recognition of an affirmative right to basic government services, including welfare); Tribe, Unraveling National League of Cities: The New Federalism and Affirmative Rights to Essential Government Services, 90 HaRv. L. REv. 1065 (1977) (same), is fanciful to the extent it is not facetious; it transforms a decision designed as a shield for state autonomy into a sword for its destruction.

so Locke wrote, "The state of nature has a law of nature to govern it, which obliges every one; and reason, which is that law, teaches . . . that, being all equal and independent, no one ought to harm another in his life, health, liberty, or possessions." J. LockE, supra note 75 , at 5 . This suggests that, even in the state of nature, one may not steal in order to avoid starvation. Some ambiguity is present, however, in Locke's further statement that, "when his own preservation comes not in competition," one ought "as much as he can, to preserve the rest of mankind, and may not, unless it be to do justice to an offender, take away or impair the life, or what tends to the preservation of the life, the liberty, health, limb, or goods of another." Id. at 6. "Preservation" here might mean self-defense, or it might include the necessity to avoid starvation.

81 For example, see Cantwell v. Connecticut, 310 U.S. 296 (1940), where the defendant's insufficiently harmful statements had been singled out for prosecution under a breachof-the-peace ordinance. Although the Court did not explicitly base its decision on the presence of discrimination, its rhetoric sounded in equal protection: 
absence of standards to limit administrative discretion may be explained as prophylactic decisions to guard against the risk of undetected inequality and thus are similarly unhelpful. ${ }^{82}$ But neither of these explanations applies to a case like Schneider v. State, ${ }^{83}$ where the Court held that certain municipalities had abridged freedom of expression by impartially forbidding everyone to distribute handbills on streets and sidewalks. ${ }^{84}$

In form the state was a traditional aggressor in Schneider. It had forbidden private action, and it had sought to deprive the violators of their liberty or property as punishment. Perhaps that is why the Court had no great difficulty in concluding that the state had abridged the freedom of speech. But in substance what the state had done was to refuse to make its property available to the public to facilitate private expression-just as by outlawing theft from the treasury a state reinforces its decision not to make additional contributions to alleviate the misery of the poor. ${ }^{86}$

It is true that, as in the contract and property cases, the arguably affirmative duty to make public property available for speaking is a conditional one. It arises only after the government has made an initial decision to devote the property to certain uses, for not all public property has been held to be a public forum. ${ }^{86}$ In contrast to the contract and property cases, however, the duty is one of protection against impersonal influences such as the limited availability of funds, not against the actions of third parties. In any event, the fact that the public forum doctrine has been based in substantial part upon an understanding of the role that streets and

In the realm of religious faith . . . sharp differences arise. . . [T] [Te tenets of one man may seem the rankest error to his neighbor. . . . But the people of this nation have ordained in the light of history, that, in spite of the probability of excesses and abuses, these liberties are . . . essential to enlightened opinion and right conduct on the part of the citizens of a democracy.

Id. at 310 .

s2 See, e.g., Cox v. Louisiana, 379 U.S. 536, 557 (1965) (stressing the risk of selective enforcement under a standardless permit requirement).

ss 308 U.S. 147 (1939).

84 For the texts of the ordinances, see id. at 154-57. One of the challenged municipal ordinances allowed the distribution of literature, but only after a permit had been obtained from the local authorities. The Court struck this provision down on the grounds that it gave the authorities discretion to choose which ideas could be disseminated. Id. at 164 .

ss It does not seem helpful to explain that streets and parks are the property of the people themselves and not of the state. If that is anything more than a restatement of the conclusion, it leaves out of sight the fact that the state holds public moneys, too, only as a trustee for the people.

${ }^{88}$ See, e.g., Adderley v. Florida, 385 U.S. 39, 41 (1966) (upholding a conviction for trespass on jail premises because "jails, built for security purposes," are not traditionally open to the public). 
parks have traditionally played in the struggle for free speech, ${ }^{87}$ together with the formally aggressive nature of the government actions taken in these cases, should inhibit extension of the publicforum precedents to other liberties that might be found equally important and equally dependent upon government aid for their realization.

\section{Equal Prote}

1. The Original Understanding. The equal protection clause is regarded today as a general prohibition of discriminatory state action that largely functions, like most of our constitutional provisions, to prohibit active governmental aggression. The state may not, for example, forbid eighteen-year-old men to drink if it does not impose the same disability on eighteen-year-old women. ${ }^{88}$ Both the language and the history of the clause, however, suggest that it may have had an original purpose that is more relevant to the present inquiry.

As Justice Miller noted in his opinion for the Court in the Slaughter-House Cases, ${ }^{89}$ the southern states had not only enacted Black Codes denying blacks a number of privileges and immunities; they had also, by failing to protect blacks against the depredations of others, left them "at the mercy of bad men." Civil Rights Act addressed both of these problems, providing not only that blacks should enjoy equal contractual and other rights and be subject to no special penalties, but also that citizens of all races should be entitled to the "full and equal benefit of all laws and proceedings for the security of person and property, as is enjoyed by white citizens." ${ }^{91}$ In other words, if the state uses its criminal and tort laws to protect whites from other people, it must do the same for blacks.

The major impetus behind the adoption of the fourteenth amendment, according to the overwhelming testimony of members of Congress who voted to propose it, was to provide an unshakable constitutional base for these provisions. The language of the amendment, moreover, was admirably designed to do just that. The privileges or immunities clause seems to extend the nondiscrimination principle of article IV respecting such matters as con-

${ }^{87}$ See Hague v. CIO, 307 U.S. 496, 515 (1939) (plurality opinion by Justice Roberts).

8 See, e.g., Craig v. Boren, 429 U.S. 190 (1976).

s9 83 U.S. (16 Wall.) 36 (1873).

so Id. at 70 .

${ }^{91}$ Act of Apr. 9, 1866, ch. 31, § 1, 14 Stat. 27. 
tractual capacity and criminal penalties to a state's own citizens, without regard to race; the equal protection clause appears to require the states to afford blacks the same protection against others as they afford whites. ${ }^{92}$

The Supreme Court's narrow interpretation of the privileges or immunities clause ${ }^{93}$ has induced it to read the equal protection clause to absorb the function of protection against discrimination in the distribution of rights and penalties. But the Court has never denied that the equal protection clause also serves its original function of requiring the state to protect blacks against third parties to the extent it protects whites. It is true that, so far as this clause is concerned, a state could theoretically avoid any affirmative obligation by refusing altogether to forbid murder or theft. Since that is hardly a realistic possibility, however, tying the rights of the minority to those of the dominant group seems the practical equivalent of creating an affirmative duty of protection, and even in theory it sometimes imposes a duty of affirmative government action.

2. Equality in the Provision of Other Services. In Shapiro v. Thompson $^{\text {94 }}$ the Court held it unconstitutional to exclude individuals from participation in a welfare program on the ground that they had not yet lived in the state for a year. The basis was equal protection: there was no sufficient justification for distinguishing between old and new residents for this purpose.95

Again there was no suggestion that, as would presumably be decided in Germany, the state was under any obligation to provide welfare benefits to anyone in the first place. The only requirement being equality, in theory the state could have corrected the constitutional flaw by abolishing its entire welfare program. Nevertheless, Shapiro confirms in the context of governmental services generally the conditional affirmative duty already discussed in connection with protection against third parties: if government undertakes to help $A$, it may have to help $B$ as well. Its duty will depend, of course, upon whether the Court finds $A$ and $B$ to be similarly situated; and the Court will not always scrutinize the dis-

92 For a discussion of the history of the adoption of the fourteenth amendment and this theory of its structure, see D. CURRIE, supra note 9 , at $345-51$, and the authorities cited therein.

${ }^{23}$ See, e.g., The Slaughter-House Cases, 83 U.S. (16 Wall.) 36, 74-78 (1873); D. CuRRIE, supra note 9 , at 342-51 (discussing the Court's treatment of the clause).

* 394 U.S. 618 (1969).

DF Id. at 627. The Court also invoked the due process clause of the fifth amendment to hold unconstitutional a similar requirement adopted by Congress. Id. at 642 . 
tinction as strictly as it did in Shapiro, where it found discrimination against those exercising a constitutional right to travel.98 When a violation is found, however, the practical effect may often be the same as if there were an absolute duty to provide services, for in the modern world it is almost as unthinkable for a state to abandon welfare payments as to stop punishing crime.

3. The Meaning of Equality. I have dismissed some of the decisions involving the assignment of counsel as adding little to the concept of positive rights against the government. Another rightto-counsel case, however, is among several equal protection decisions suggesting a more sweeping theory of affirmative governmental obligations.

In Douglas v. California ${ }^{97}$ in 1963 , the Court invoked not the right to counsel or due process but equal protection to hold that a state must provide counsel to represent an indigent on appeal..$^{98}$ In so holding, the Court relied upon Griffin $v$. Illinois, ${ }^{98}$ which had required the state to furnish an indigent with a free transcript of the trial: "In criminal trials," wrote Justice Black in Griffin, for a plurality whose views became those of the majority in Douglas, "a State can no more discriminate on account of poverty than on account of religion, race, or color."100 A similar argument informed the Court's decision in Harper v. Virginia Board of Elections ${ }^{101}$ that equal protection forbade the state to make payment of a poll tax a condition of voting: "Wealth, like race, creed, or color, is not germane to one's ability to participate intelligently in the electoral process."102

In neither Griffin nor Douglas was there any doubt that the state was depriving the defendants of life, liberty, or property in the traditional sense; as in the other right-to-counsel cases, the state was seeking the imposition of criminal penalties. Thus again, the narrow holdings entail no more than a definition of how the government must proceed when it acts aggressively against the individual. ${ }^{103}$ The same may be true of Harper, where the state had

o6 Id. at 629-31 (noting the historical importance of the right to travel).

o7 372 U.S. 353 (1963).

${ }^{28}$ Id. at $357-58$.

9031 U.S. 12 (1956).

100 Id. at 17.

101383 U.S. 663 (1966).

102 Id. at 668.

${ }^{103}$ The Court emphasized this aspect of the matter in its most recent foray into this field, holding that due process required a state to furnish psychiatric assistance to an indigent criminal defendant whose sanity at the time of the offense is in question: "[W]hen a State brings its judicial power to bear on an indigent defendant in a criminal proceeding, it 
attempted to prevent the citizen from exercising the privilege of voting - which can hardly be viewed as the provision of an affirmative governmental service. What is of interest is the reasoning that led the Court to these results, for it embodies a concept of equality that could require affirmative governmental action in a much broader range of situations.

Justice Harlan put his finger on the crucial point in dissents in both Douglas and Griffin. In neither case had the state explicitly drawn a distinction based on wealth. In one sense it had treated everyone identically: everyone was entitled to counsel and a transcript on appeal, but only at his own expense. If some people could not afford them, that was not the state's fault: "All that Illinois has done is to fail to alleviate the consequences of differences in economic circumstances that exist wholly apart from any state action. The Court thus holds that . . . the Equal Protection clause imposes on the States an affirmative duty to lift the handicaps flowing from differences in economic circumstances."104

This concept of equality has potential consequences far beyond the limited context of criminal proceedings in which the government seeks to deprive the individual of life, liberty, or property. It seems equally applicable to the distribution of government services; as Justice Harlan suggested, the same principle would require a state to charge the poor less than the rich for water or for graduate education, since all uniform charges bear more heavily on the poor than they do on others. ${ }^{105}$ Equality would be judged, in other words, not by the action of the state but by its effect on the individual; and whenever the government acted it would have to compensate for inequalities of wealth for which it was not responsible. ${ }^{108}$

must take steps to assure that the defendant has a fair opportunity to present his defense," stressing that in the criminal proceeding "his liberty is at stake." Ake v. Oklahoma, $105 \mathrm{~S}$. Ct. 1087, 1093 (1985). Similarly, in basing the invalidation of a filing fee for divorce actions on due process rather than equal protection in Boddie v. Connecticut, 401 U.S. 371 (1971), Justice Harlan noted that by monopolizing the means for legally dissolving the marriage relationship and charging a filing fee the state had actively deprived the poor of the right to end marriages. Id. at 380-81. The "affirmative" obligation to provide a forum arose only because the state had imposed duties on the individual that could be terminated only by judicial action. Id. at 376 .

${ }_{104}$ Griffin, 351 U.S. at 34 (Harlan, J., dissenting); see also Douglas, 372 U.S. at 362 (Harlan, J., dissenting) ("The State may have a moral obligation to eliminate the evils of poverty, but it is not required by the Equal Protection Clause to give to some whatever others can afford.").

${ }^{105}$ Douglas, 372 U.S. at 361-62.

108 In the German cases there is a strong strain of this theory of equality. In one case, for example, the German court invalidated on equality grounds a provision that made all 
Even if this proposition and all of its implications were accepted, it would not be the equivalent of a general command to eradicate differences in wealth, since like other applications of equal protection it presupposes some government action. Moreover, the Court has shown no inclination to extend the principle beyond cases in which the government has acted intrusively, though that fact seems irrelevant to the theory. ${ }^{107}$ Nevertheless, cases like Douglas, Griffin, and Harper suggest once again that the Court is sometimes willing to find in negatively phrased constitutional provisions some form of affirmative government obligation.

4. Extension of the State Action Concept. In Shelley $v$. Kraemer, ${ }^{108}$ the Court prohibited the state from enforcing a racially restrictive covenant as it would enforce any other covenant. In so doing, the Court made it clear that state neutrality was not always enough to satisfy the equal protection clause; if the state acted at all, it had to take sides against private discrimination. ${ }^{109}$ Since there was no doubt the state was using its coercive powers against the defendant, this case too involved typical state aggression. Like the theory of equality employed in Douglas and Griffin, however, Shelley's concept of state responsibility had implications not limited to that type of case.

In Burton v. Wilmington Parking Authority, ${ }^{110}$ for example, the state was held responsible for discrimination by a private firm

campaign contributions deductible from income taxes, on the ground that they benefited wealthy taxpayers more than others and therefore worked to the practical advantage of the more conservative party. In the same spirit, the court added a dictum that equality required that taxes be progressive. BVerfG $8,51,68$ (1958). It need hardly be added that it would be difficult to attribute any such notion of equality to the framers of the fourteenth amendment.

${ }^{107}$ Indeed, the general principle that one must look to the effects rather than the basis of government action to determine whether or not it offends the equal protection clause has received important setbacks in the area of so-called de facto discrimination in hiring. See Washington v. Davis, 426 U.S. 229, 239 (1976) (denying that the Court's decisions have "embraced the proposition that a law . . . , without regard to whether it reflects a racially discriminatory purpose, is unconstitutional solely because it has a racially disproportionate impact") (emphasis in original).

${ }^{108} 334$ U.S. 1 (1948).

108 The Court stated that the fourteenth amendment is not "ineffective simply because the ... discrimination, which the State has enforced, was defined initially by the terms of a private agreement. ... [W] [Wen the effect of [state] action is to deny rights subject to the protections of the Fourteenth Amendment, it is the obligation of this Court to enforce the constitutional commands." Id. at 20 . It is interesting to note, in light of the above discussion of the contract and property cases, that the Court gave short shrift to the argument that property owners had a right of access to the courts for a remedy: "The Constitution confers upon no individual the right to demand action by the State which results in the denial of equal protection of the laws to other individuals." Id. at 22.

130365 U.S. 715 (1961). 
that had leased state property. ${ }^{111}$ Again there was no doubt that the state had taken action in entering the lease; but, as in Shelley, it was not the state that had decided to discriminate. The decision may be said to have placed an affirmative burden on the state, if it leases at all, to forbid discrimination by its private lessees. ${ }^{112}$

Reitman $v$. Mulkey ${ }^{113}$ may have gone even further. There the Court prohibited the state from enacting a constitutional provision forbidding the adoption of fair-housing laws. ${ }^{114}$ In Reitman, the state had not implicated itself in the decision to discriminate either by enforcing a private decision, as in Shelley, or by making its property available to the discriminator, as in Burton. What the state had done, however, was to stop forbidding private discrimination with which it had no active connection.

There were those who defended the decision flatly on the ground that the state had an affirmative duty to prevent private discrimination. ${ }^{115}$ Such a conclusion would effectively overrule the Civil Rights Cases $^{116}$ and leave the fourteenth amendment's explicit state-action limitation without meaning. It would also be the most far-reaching example we have encountered of an affirmative state duty to help the individual.

Later cases like Moose Lodge No. 107 v. Irvis ${ }^{117}$ and Jackson v. Metropolitan Edison Co., ${ }^{118}$ however, have shown that the Court is not prepared to take the principle so far. Moreover, the Court in Reitman itself expressly disclaimed any intention of imposing on the state a duty to prevent private discrimination, suggesting instead that the state could have simply repealed the fair-housing

111 Id, at 725 .

112 More particularly, Burton stands for the principle that a state which enters into a "symbiotic relationship" with a private individual or entity, each conferring mutual benefits on the other, may be held responsible for the private party's discriminatory conduct. Whether the state and the private party have such a relationship depends upon the particular circumstances of the case. Id. at 724-25.

113387 U.S. 369 (1967).

114 Id. at 381 .

11 See, e.g., Karst \& Horowitz, Reitman v. Mulkey: A Telophase of Substantive Equal Protection, 1967 Sup. CT. Rev. 39, 57.

110109 U.S. 3 (1883).

117407 U.S. 163 (1972). In Moose Lodge, the Court held that the refusal of a private club to allow black guests did not violate the fourteenth amendment even where the club was licensed and regulated by the state. Id. at 177. The Court refused to hold that the presence of any connection between the private entity and the state was sufficient to convert the private entity's conduct into state action, noting that this would "utterly emasculate" the state action requirement. Id. at 173.

118419 U.S. 345 (1974). In Jackson, the Court held that a public utility's termination of electric service without a hearing did not violate due process because the heavily regulated and monopolistic utility was not a "state actor." Id. at 358. 
laws without running afoul of the Constitution. ${ }^{110}$ The Court emphasized that by enshrining the right to discriminate in its constitution the state had rendered it "immune from legislative, executive, or judicial regulation at any level of the state government."120 Though the significance of this fact was not spelled out in the Reitman opinion, subsequent decisions suggest the Court may have meant that by erecting unusual barriers to the enactment of fair-housing laws the state had discriminated against the beneficiaries of such laws in a much more traditional sense. ${ }^{121}$ Nevertheless, there remain suggestions of limited affirmative duties in modern state-action cases, where the state has taken any action at all.

\section{CONCLUSION}

Judge Posner's position that "the Constitution is a charter of negative rather than positive liberties"122 has great intuitive appeal. It finds support in the constitutional language, in Supreme Court decisions, and in the history of the Bill of Rights as a safeguard against governmental intrusion. My survey of the cases leaves me convinced, as Judge Posner implies, that in this country government need not actively support everything it may not forbid. The contrast with the German decisions remains striking.

I think, however, that this survey has shown Judge Posner's proposition must be applied with caution. From the beginning there have been cases. in which the Supreme Court, sometimes very persuasively, has found in negatively phrased provisions constitutional duties that can in some sense be described as positive. When government acts to deprive the citizen of life, liberty, or property, for example, it may have to furnish a judicial remedy to test the legality of its action as well as legal services and materials to en-

210387 U.S. at 376.

220 Id. at 377. This kind of invulnerability from attack was held to "involve the State in private discrimination to an unconstitutional degree." Id. at 378-79; see also id. at 376 (noting that the court below, whose arguments the Justices seemed to endorse, had conceded that the state was not required to outlaw private discrimination).

${ }_{122}$ See Hunter v. Erickson, 393 U.S. 385, 391 (1969) (automatic referendum requirement applicable only to fair-housing ordinances held invalid as placing a "special burden" on minorities); Washington v. Seattle School Dist. No. 1, 458 U.S. 457, 485-86 n.29 (1982) (a "state's race-conscious restructuring of its decisionmaking process" in order to prevent a school district from ordering busing is "impermissible"). For commentary explaining Reitman on this basis, see Black, Foreword: "State Action," Equal Protection, and California's Proposition 14, 81 Harv. L. Rev. 69, 82 (1967), and Winter, Poverty, Economic Equality, and the Equal Protection Clause, 1972 Sur. CT. Rev. 41, 50.

${ }^{122}$ Jackson v. City of Joliet, 715 F.2d 1200, 1203 (7th Cir.) (discussed supra note 1 and accompanying text), cert. denied, 465 U.S. 1049 (1983). 
able the indigent object of its action to defend. When government has disabled the individual from obtaining his own medical or religious services by incarcerating him, it may have to provide them. When government protects some people either from third parties or from impersonal hardships, it may have to protect others as well. When government takes action that facilitates private discrimination, it may have to outlaw private action. When it decides to maintain a street or a park, it may have to make the property, available as a public forum. Once it provides remedies for the protection of private contract or property rights, it may have to continue affording them.

The cases suggest that some clauses are more likely to be interpreted to have "positive" components than others. The contract and property provisions seem particularly susceptible to such interpretation, because they plainly forbid government to interfere with rights against private parties the value of which is largely dependent upon government protection. The obligation to provide government property for the exercise of constitutional rights is especially strong in the speech context for historical reasons and especially weak in that of religion because of the countervailing force of the establishment clause.

Moreover, within a single clause the discovery of one "affirmative" duty does not necessarily compel the discovery of another. The contract clause requires some protection against third parties, but none against the elements. Freedom of speech may require the state to open its parks but not its treasury. Equal protection by its terms imposes only the conditional duty to help one person to the extent the government helps another who is similarly situated.

One should not quibble over the question whether the rights acknowledged in these cases are in some linguistic or logical sense "really" positive. What is important is that one not take Judge Posner's valuable insight as a talisman capable of resolving a broad spectrum of problems against the existence of governmental duties that can in some sense be deemed affirmative. In other words, it would be dangerous to read too much, even at the theoretical level, into the generally valid principle that ours, unlike the German, is a Constitution of negative rather than positive liberties.

At the practical level the distinction may be of even less significance. On the one hand, the unlikelihood that such affirmative services as welfare payments and criminal laws will be abandoned may make our traditional equal protection principle the practical 
equivalent in many cases of an absolute duty to provide them. ${ }^{123}$ On the other hand, despite their rhetoric, all of the German decisions involve areas in which there has been an effective government monopoly: broadcasting, higher education, and the use of force. In each case one might plausibly have argued that government action had made it impossible for the individual effectively to exercise a constitutional right without government assistance..$^{124}$ And if that is so, in their results the German decisions are essentially of a piece with our courts' unsurprising and traditional conclusion that a state must provide medical care to those it has imprisoned. ${ }^{225}$

Equally informative, moreover, is the degree of restraint the German court has exercised in determining the scope of such affirmative duties as it has discovered. Only in the abortion and television cases has that court so far found the government's affirmative action wanting. In other cases, while enunciating a general governmental duty, it has emphasized the government's broad discretion in determining how much money to invest in educational facilities, or how to protect against terrorism, or how to resolve competing interests in environmental disputes. ${ }^{126}$ To a very substantial extent the degree of affirmative obligation that exists seems to depend not on the reigning theory but on the degree of aggressiveness or deference with which the courts apply it. ${ }^{127}$

${ }^{123}$ See, for example, the equal-protection arguments made in connection with abortion funding, discussed supra note 13.

${ }^{124}$ See Denninger, supra note 35, at 261 (finding the argument for affirmative rights at its strongest "when the state, as in higher education, disposes of the prerequisites to the effectuation of a fundamental right in effectively monopolistic fashion") (author's translation).

${ }^{125}$ Thus the affirmative duties imposed on the German government in the television cases, discussed supra at notes 37-40 and accompanying text, might have been justified in traditional American terms on the ground that by requiring broadcast licenses and limiting their number the government had actively abridged the freedom of nonlicensees to communicate over the air. Cf. CBS v. Democratic Nat'l Comm., 412 U.S. 94, 114-121 (1973) (reserving the issue of state action in a suit seeking to impose affirmative duties on broadcasters under the first amendment); Moose Lodge No. 107 v. Irvis, 407 U.S. 163, 177 (1972) (holding that the state's restriction of the number of liquor licenses available in a given community did not implicate the state in the discriminatory policies of the private club to which it had granted a license).

${ }^{228}$ Even in the abortion field the practical differences are far smaller than one might have imagined: a general escape formula allowing abortions in casès where "socially" indicated softens the German situation to one perhaps not so distant from our own. See BVerfG 39,50 (1975).

${ }^{127}$ One is tempted to suggest, indeed, that the more general and abstract a legal theory is the less likely it is to be of much utility in resolving actual cases. Cf. Associated Indus. v. Department of Labor, 487 F.2d 342, 349-50 (2d Cir. 1973) (doubting that it made any practical difference whether regulations of the Occupational Safety and Health Administration 
Indeed there are observers who suggest that, practically speaking, affirmative constitutional rights are inherently unlikely ever to become much more than pious exhortations to the political branches of government. In contrast to traditional defensive rights, it is argued, rights to participate in the provision of government services have such imprecise boundaries that their effectuation is not to be expected without legislative and executive definition: "For this reason social rights such as the right to protection of the family, motherhood, and youth cannot be captured by an enforceable, abstract norm." ${ }^{128}$ This conclusion is backed up by the observation that, notwithstanding the worldwide proliferation of constitutional provisions explicitly imposing affirmative social duties, "[n]o constitution recognizing the rule of law has yet actually succeeded in practice" in turning away from the classical negative understanding of fundamental rights. ${ }^{129}$

Does this mean we must despair of achieving the altruistic social state to which the Germans aspire, the fraternite for which, in part, the French Revolution was fought? Not at all. As the same author who argued for the futility of constitutionalizing social rights observed, West Germany has to a large degree achieved its aspiration, though not by the enforcement of positive constitutional rights; ${ }^{180}$ and so have we. With a little help from the equal protection clause, we have done so essentially by the means contemplated by constitution-makers who chose not to enshrine social rights: by political forces reflected in legislative and executive action.

were reviewed under the "arbitrary and capricious" standard or the "substantial evidence" rule); D. CuRRIE, supra note 9, at 320-29 (describing how identical verbal formulas respecting the meaning of the necessary and proper clause were used to achieve totally divergent results by majority and dissenting opinions in Hepburn v. Griswold, 75 U.S. (8 Wall.) 603 (1870) (invalidating paper tender)).

${ }^{128}$ Forsthoff, supra note 47, at 11-12.

129 Id. at 20, 33 (discussing, inter alia, the French and German provisions noted supra at notes 7, 20-47). Another humble example is article XI, $\S 2$ of the 1970 Illinois Constitution, which bravely gives every person a "right to a healthful environment," enforceable against "any party, governmental or private," and which has proved a dead letter.

There are special reasons why an effort to impose affirmative constitutional rights would risk futility in the United States. The enforcement of affirmative duties upon the Federal government would pose particular problems: the executive cannot be ordered to spend money that Congress has not appropriated, and Congress cannot be ordered to make an appropriation. See U.S. CoNST. art I, § 6 ("for any Speech or Debate in either House, [Senators and Representatives] shall not be questioned in any other Place"); id. § 9 ("[n]o Money shall be drawn from the Treasury, but in Consequence of Appropriations made by Law"); see also Eastland v. United States Servicemen's Fund, 421 U.S. 491 (1975) (holding that the speech and debate clause prohibited an injunction against members of Congress).

130 Forsthoff, supra note 47. 
When liberty lives in the hearts of men, said Learned Hand, no constitution is needed to preserve it; when it dies there, no constitution can save it. ${ }^{131}$ I would not draw from this the conclusion that we might as well dispense with constitutions, though the English have managed pretty well without one; I think we can point to occasions on which a constitution has made a difference. ${ }^{132}$ But there is enough truth in Hand's observation to make us think twice about considering a set of positive constitutional rights as either a necessary or a sufficient condition for the achievement of the social state, and more than twice about the advisability of taking liberties with the Constitution to find them.

131 Learned Hand, The Spirit of Liberty, in The SpIrit of Liberty 189-90 (2d ed. 1954). As evidence in support of this thesis one might cite the conspicuous failure of the first amendment to protect us against the Sedition Act, the excesses of Espionage Act prosecutions during and after the First World War, or McCarthyism.

132 Two recent examples in which judicial interpretations of the Constitution have profoundly altered the practical situation are the reapportionment and abortion cases. E.g., Reynolds v. Sims, 377 U.S. 533 (1964); Roe v. Wade, 410 U.S. 113 (1973). 